Bayero Journal of Pure and Applied Sciences, 6(1): $72-78$

Received: February 2012

Accepted: June 2013

ISSN $2006-6996$

\title{
EFFECTS OF SPENT ENGINE OIL POLLUTED SOIL AND ORGANIC AMENDMENT ON SOIL CHEMICAL PROPERTIES, MICRO-FLORA ON GROWTH AND HERBAGE OF TELFAIRIA OCCIDENTALIS(HOOK F).
}

\author{
Osaigbovo, A. U. ${ }^{1}$, Law-Ogbomo, K. E. ${ }^{1 *}$ and Agele, S. $0^{2}$. \\ ${ }^{1}$ Department of Crop Science, Faculty of Agriculture, University of Benin, PMB 1154, Benin City, Nigeria \\ ${ }^{2}$ Department of Crop, soil and Pest Management, School of Agriculture and Agricultural Technology, Akure \\ *Correspondence author: Kolalawogbomo@yahoo.com
}

\begin{abstract}
A trial was conducted at the Screen House of the Department of Crop Science, University of Benin, Benin City, Nigeria to evaluate the efficacy of using organic fertilizer as bioremediant for spent engine oil polluted soils. Three concentrations of spent engine oil ( 0,5 and $10 \% \mathrm{w} / \mathrm{w}$, spent engine oil in soil) and three application rates of organic fertilize $\left(0,5\right.$ and $10 t$ ha $\left.^{-1}\right)$ were utilized in a $3 \times 3$ factorial arrangement and laid out as a completely randomized design with three replication. Soil pH, available $P$ and exchangeable cations were significantly reduced by spent engine oil except organic C compared to control. Heavy metals (Va and Pb) concentration increased with increasing concentration of spent engine oil. Amendment of spent engine oil polluted soil with organic fertilizer significantly remediated the degraded soil and decreases the heavy metal concentration. In addition, $10 \mathrm{tha} \mathrm{a}^{-1}$ organic fertilizer showed superiority over 5 tha ${ }^{-1}$ organic fertilizer in amending spent engine oil degraded soil for $\mathrm{pH}$, total $\mathrm{N}$, available $\mathrm{P}$, exchangeable $\mathrm{Ca}^{2+}$ and reduced heavy metal concentration. Soil pollution adversely affected number of leaves, dry vine weight, dry leaf weight and herbage yield. Growth and herbage yield were much higher in organic fertilizer amended spent engine oil polluted soil, the highest herbage yield $\left(9.23 \mathrm{t} \mathrm{ha} \mathrm{a}^{-1}\right)$ was obtained from unpolluted soil treated with $10 \mathrm{t} \mathrm{ha}^{-1}$ organic fertilizer which was statistically comparable with soil polluted with $5 \%$ spent engine oil and amended with $10 \mathrm{t} \mathrm{ha} \mathrm{a}^{-1}$ organic fertilizer ( $\left.7.10 \mathrm{t} \mathrm{ha} \mathrm{a}^{-1}\right)$. Soils polluted with $5 \%$ spent engine oil had higher bacteria population compared to control, while organic fertilizer had depressing effect on soil without spent oil pollution.However, unpolluted soiltreated with $10 \mathrm{t} \mathrm{ha} a^{-1}$ organic fertilizer had the fungi $\left(0.77 \times 10^{6} \mathrm{cfu} \mathrm{g}^{-1}\right)$ population which was statistically compared to $5 \mathrm{t} \mathrm{ha} \mathrm{a}^{-1}$ organically treated soil without spent engine oil pollution $(0.76 \mathrm{x}$ $\left.10^{6} \mathrm{cfu}^{-1}\right)$. Soil polluted with spent engine oil has been bioremediated with organic fertilizer and hence put into productive use.
\end{abstract}

Keyword: Growth, herbage yield, micro-flora, organic fertilizer, spent engine oil, Telfairia occidentalis.

\section{INTRODUCTION}

Engine oil (lubrication oil) is one of the products from base oils obtained from the distillation of petroleum. It is a non-volatile liquid and lubricant important in the maintenance of motor and internal combustion engines. When used or expired and drained out from automobile or generator engine during servicing is referred to as spent engine oil. Spent engine oil hasconstituted an important source of pollution in Nigeria due to its indiscriminate disposal into space, gutter, water drains and open vacant plots.

According to Anoliefo and Vwioko (1995), contamination of open vacant plots and farmlands with petrol oils and grease is becoming more widespread problem than crude oil pollution especially in the urban areas. The impact of spent engine oil on contact with the soil ranged from depletion of nutrients especially $\mathrm{N}$ and $\mathrm{P}$, inhibition of microbial activities and degradation of soil physical properties (Amadiet al., 1993). Spent engine oil diffused into the soil on contact with the soil leading to the formation of waxy oily scum texture (Anoliefo and Vivioko, 1995).
The formation of the oily scum impeded oxygen and availability of water to biota as well as the formation of hydrophobic micro-aggregates with clay surfaces in the soil (Amadiet al., 1993). Oils in soil makes the soil condition unsatisfactorily for plants (De Jong, 1980), due to reduction in the level of available plant nutrients or a rise to toxic levels of heavymetals, such as $\mathrm{Mn}, \mathrm{Va}, \mathrm{Pb}$, etc. (Udo and Fayemi, 1975). Anoliefo and Vivioko (1995), reported that spent engine oil polluted soil caused stunted growth in plant and the effect was more pronounced with tomato than sweet pepper.

Telfairiaoccidentalis is a valuable commercial crop grown in urban and peri-urban areas in Nigeria and across the lowland humid tropics of West Africa. It is a tropical vine grown primarily for the leaves and edible seed (Fagbemiet al., 2005). In addition, the plant can be used to treat anemia, convulsion, high blood pressure, high blood cholesterol, anthritis, liver problems and inflammatory condition (Oguntola, 2011). 
In addition, diets that are rich in leaves and seeds of fluted pumpkin have been found to increase haemotological indices, improved sperm quality, reduced blood glucose levels, arrest cancers and prevent the upset andropauce (Muanya, 2012). In this study, fluted pumpkin was used to accessthe productive of soil polluted with spent engine oil and amended with organic fertilizer.

Food security in Nigeria is seriously affected by fertile plots which are fast disappearing due to ever increasing population. This has prompted the resource-poor farmers to resort to urban and periurban agriculture.Thispractice exposes farmers to soil polluted with spent oil. There is the need to find practical and cost-effective measures so as to reduce the adverse effects of spent engine oil on the soil and crops.Merklet al. (2005), reported that addition of chemical fertilizer to a crude oil polluted soil enhanced growth and performance of Brachiariabrizantha.However, large amount of chemical fertilizers are needed to sustain reasonable growth for subsequent yield under this condition (Merklet al., 2005). This would increase the cost of production and heavy drain in the country's scarce foreign reserve, and yield reduction due to soil degradation, nutrient imbalance and acidity (Ojeniyi, 2000).Simulated biodegradation of spent engine oil is being encouraged through the use of organic amendment. This approach enhancedthe activities of microbes capable of degrading petroleum hydrocarbon (Jone and Edington, 2005). The organic fertilizer can improve the physical properties of oil polluted soil, and thereby making it available for crop production (Udomet al., 2008).

This study was therefore carried out to assess the bioremediativeeffects of organic fertilizer on spent engine oil polluted soil, micro-flora and on growth and herbage yield of T.occidentalis.

\section{MATERIALS AND METHODS}

\section{Experimental Design}

This trial was conducted at the Screen House of the Department of Crop Science, Faculty of Agriculture, University of Benin, Benin City, Nigeria.Soil used for the trial was obtained from a composite sample of top soil (0-15 cm depth) collected from Forestry and Wildlife Arboretum, Faculty of Agriculture, University of Benin, Benin City. Five (5) $\mathrm{kg}\left(6463 \mathrm{~cm}^{3}\right)$ of air dried soil was measured into perforated polybags, measuring $60 \times 25 \times 15 \mathrm{~cm}$ and placed on a tray. Pre-sowing Treatment and Routine Soil Analysis

The soil used for the trial was analyzed for its routine properties before polluted with spent engine oil and amended with organic fertilizer using Mylavarapus and Kennelley (2002) procedures.Spent engine oil was obtained from amotor mechanic workshop in Benin City.Polybags designated for spent engine oil treatment were each thoroughly mixed with 0,32 and $64 \mathrm{ml}$ representing 0,5 and 10,\% w/w, spent engine oil in soil, respectively. The soils used as control were not polluted. Quantities $(0,25$ and $50 \mathrm{~g}$ ) of organic fertilizer obtained from Sunshine Fertilizer Plant, Akure were added to designated polybags and incorporated into the soil to represent 0,5 and $10 \mathrm{t} \mathrm{ha}^{-1}$ organic fertilizer. The polybags after treatments were left for two weeks to allow for equilibration. After equilibration, soil samples were taken from eachtreatment using hand auger, and bulked together. The representative samples (27) were analyzed for chemical properties using Mylavarapus and Kennelley (2002) procedures.

Fluted pumpkin seeds obtained from New Benin market, Benin City were raised in basket filled with wood shaving and grown to two seed leaf stage before transplanting into polybags at one seedling to one polybag. Weeding and pest control were done through handpicking throughout the duration of the experiment. Nipping was done on one tagged plant in each plot at four weeks after transplanting (WAT). Subsequently nipping was done at two weeks interval until the 10 WAT when the final harvesting was carried out. At final harvesting, two plants were taken from each plot for destructive sampling. Each plant was partitioned into root, vine and leaves and was dried at $70{ }^{\circ} \mathrm{C}$ to constant weight. Measurement was also made on the vine, tap root length and number of roots.

\section{Screening and Identification of Micro-flora}

Soil samples were taken from the base of each plant at a depth of $0-15 \mathrm{~cm}$ using hand auger. The augered soil were pooled together to constitute composite sample for each plot. Ten (10) g was taken from each representative sample and serial dilution was carried out. From the fifth dilution, with a pipette $1 \mathrm{ml}$ was taken for isolation of microorganisms using direct plate counting method of Collins and Lyne (1976). Microbial population was determined for each treatment and different microbial species were isolated based on their colony morphology, characterized and identified based on the method of Fawole and Oso (1988).

Statistical Analysis

All data collected were subjected to a combined analysis of variance using GENSTAT programme version 8.1 (GENSTAT, 2005). The Least Significant Differences (LSD) Test was used to detect significant differences between treatment means at $5 \%$ level of probability.

\section{RESULTS AND DISCUSSION}

The physical and chemical properties of the soil before pollution with spent engine oil are given in Table 1.The soil was sandy clay loam, acidic ( $\mathrm{pH} 5.00)$, low in total $\mathrm{N}$ and exchangeable $\mathrm{K}$ and moderate in organic C (2.08\%), available $P\left(5.70 \mathrm{mg} \mathrm{kg}^{-1}\right)$, exchangeable Ca $\left(0.70 \mathrm{cmol} \mathrm{kg}^{-1}\right)$ and $\mathrm{Mg}(0.60 \mathrm{~mol}$ $\mathrm{kg}^{-1}$ ).

Table 2 shows some chemical properties of the soil after pollution with spent engine oil and amended with organic fertilizer. Spent engine oil depressed soil $\mathrm{pH}$ and decreased with increase in spent engine pollution. The soil $\mathrm{pH}$ decreased from 5.00 prior to pollution to 4.42 with $10 \%$ pollution concentration. Organic C content of the soil increased as the concentration level of spent engine oil increased. 
This was due to the fact that the principal constituent of spent engine oil was carbon and hydrogen (Baeket al., 2004).Spent engine oil polluted soil has no significant effect on total $\mathrm{N}$. Available $\mathrm{P}$ decreased from 7.05 to $3.56 \mathrm{mg} \mathrm{kg}^{-1}$. This is in agreement with Ogboghodoet al. (2005).

The content of exchangeable bases in spent oil polluted was relatively lower than the unpolluted soil. Exchangeable $\mathrm{Ca}$ decreased from 0.67 to $0.41 \mathrm{cmol}$ $\mathrm{kg}^{-1}$ after exposure with $10 \%$ spent engine oil pollution. Similarly, exchangeable $\mathrm{K}$ decreased from 0.23 to $0.16 \mathrm{cmol} \mathrm{kg}^{-1}$ and exchangeable $\mathrm{Mg}$ from 0.66 to $0.54 \mathrm{cmol} \mathrm{kg}^{-1}$ after impact with $10 \%$ spent engine oil pollution. There were increases in the concentration of heavy metals ( $\mathrm{Va}$ and $\mathrm{Pb}$ )as the level of spent engine oil pollutionincreased.Va was not present in unpolluted soils and was added to the soil through spent engine oil pollution and increased with increase in pollution concentration.Va came from the wear and tear of engine parts (ATSDR, 1997). The reduction in the level of available plant nutrients and rise in the level of heavy metal concentrations is in agreement with the view of Udo and Fayemi (1975).Pb content increased by 250 and $400 \%$, respectively for 5 and $10 \%$ spent engine oil pollution. Generally, organic fertilizer significantly increased organic $\mathrm{C}$, total $\mathrm{N}$, exchangeable cations and decreased heavy metal content. The nutrient increased is in the order of $10>5>0 \mathrm{t} \mathrm{ha}^{-1}$ organic fertilizer. In addition, $\mathrm{pH}$ increased with organic fertilizer application. This liming effect was attributed to the release of cations. The soil $\mathrm{pH}$ is a major factor influencing the availability of nutrients in the soil for plant uptake (Marchner, 1995)

Interactive effects of spent engine oil and organic fertilizer on soil chemical properties arepresented in Table 3. These were significant for organic $\mathrm{C}$, available $\mathrm{P}$, exchangeable $\mathrm{Ca}$, and $\mathrm{K}$ and heavy metal ( $\mathrm{Va})$. There was higher organic $\mathrm{C}$ in soil amended with organic fertilizer than soils without organic fertilizer. The percentage organic $C$ content of soil polluted with spent engine oil and amended with organic fertilizer was significantly higher than that of soil without organic fertilizer. Soils polluted with $10 \%$ spent engine oil concentration and amended with $10 \mathrm{t} \mathrm{ha}^{-1}$ organic fertilizer had highest organic C (3.84\%). The high organic $\mathrm{C}$ exhibited by organic fertilizer treated plots enhanced microbial activities for effective remediation of spent engine oil polluted soil (Adedokun and Ataga, 2007).

Available $\mathrm{P}$ was significantly decreased by spent engine oil and increased by organic fertilizer through its effect on $\mathrm{pH}$. Low $\mathrm{pH}$ increased phosphate sorption and decreased as $\mathrm{pH}$ increased. The highest available was $8.80 \mathrm{mg} \mathrm{kg}^{-1}$ observed from plots treated with 10 $\mathrm{t} \mathrm{ha}^{-1}$ organic fertilizer without spent engine oil pollution. Soil polluted with spent engine oil and amended with organic fertilizer had significantly higher exchangeable $\mathrm{Ca}$ and $\mathrm{Mg}$ than soils polluted with spent engine oil alone. Exchangeable Ca content of the soil varied from $0.30 \mathrm{cmol} \mathrm{kg}^{-1}$ in soils polluted with $10 \%$ spent engine oil concentration to $0.67 \mathrm{cmol}$ $\mathrm{kg}^{-1}$ in soils treated with either 5 or $10 \mathrm{t} \mathrm{ha}^{-1}$ organic fertilizer without spent engine oil pollution. The highest exchangeable $\mathrm{K}$ was produced from soils fortified with $10 \mathrm{t} \mathrm{ha}^{-1}$ organic fertilizer.

Va was absent in unpolluted soils and presence in spent engine oil polluted plots. However, amended spent engine oil polluted soil with organic fertilizer drastically reduced $V a$ concentration.

Spent engine pollution reduced number of leaves of $T$. occidentalis with the lowest recorded in the absence of organic fertilizer (Tables 4 and 5). The unpolluted plots gave the highest number of leaves at two (21.67) and four (36.40) WAT when compared to polluted plots. However, plants in plots that received organic fertilizer significantly had higher number of leaves in all sampling periods. The observed reduction in the number of leaves in spent oil polluted soils compared to unpolluted soils could probably be due to lower Total $\mathrm{N}$ content of the polluted soils.

There was significant interactive effect $(P>0.05)$ between spent engine oil and organic fertilizer at two WAT (Table 5). Plots treated with $10 \mathrm{t} \mathrm{ha}^{-1}$ organic fertilizer had the highest number of leaves but was at par with plots polluted with $10 \%$ spent engine oil and amended with $10 \mathrm{t} \mathrm{ha}^{-1}$ organic fertilizer.

Spent engine oil pollution had no significant effects on tap root length, number of roots, vine length and dry root weight. Dry vine weight, leaf weight and herbage yield were significantly higher in control than in polluted plots (Table 6 ). This could be attributed to heavy metal toxicity and poor soil aeration (Anoliefo and Vwioko, 1995). On the contrary, increasing organic fertilizer application rate led to increase in growth and herbage yield parameters. Control plots had the least vine length $(45.90 \mathrm{~cm})$, dry vine weight $(1.93 \mathrm{~cm})$, dry root weight $(5.49 \mathrm{~g})$, dry leaf weight $(5.39 \mathrm{~g})$ and herbage yield $\left(4.36 \mathrm{t} \mathrm{ha}^{-1}\right)$ (Table 6). The highest values of these parameters were observed from $10 \mathrm{t} \mathrm{ha}^{-1}$ organic fertilizer treated plots.

The interactive effects of spent engine oil and organic fertilizer on dry leaf weight and herbage yield were significant (Table 7). Unpolluted plots treated with 10 $\mathrm{t} \mathrm{ha}{ }^{-1}$ organic fertilizer had the highest dry leaf weight $(20.28 \mathrm{~g})$ and herbage yield $\left(9.23 \mathrm{t} \mathrm{ha}^{-1}\right)$. However, this value was not significantly different from $5 \%$ polluted plots amended with $5 \mathrm{t} \mathrm{ha}^{-1}\left(7.22 \mathrm{t} \mathrm{ha}^{-1}\right), 10 \mathrm{t}$ $\mathrm{ha}^{-1}\left(7.10 \mathrm{t} \mathrm{ha}^{-1}\right)$ organicfertilizer and $10 \%$ spent engine oil polluted plots treated with $10 \mathrm{t} \mathrm{ha}^{-1}$ (9.15 t $\left.\mathrm{ha}^{-1}\right)$. The enhancement of growth by organic fertilizer could be attributed to increased mineralization and ameliorative effect on the polluted soil providing a good nutrient base for plant to explore.

Spent engine oil pollution significantly influenced the microbial count (Table 8). Plots polluted with $5 \%$ spent engine oil gave the highest bacteria population with $3.23 \times 10^{6} \mathrm{cfu} \mathrm{g}^{-1}$ and the least was obtained from unpolluted (control) plots $\left(2.75 \times 10^{6} \mathrm{cfu} \mathrm{g}^{-1}\right)$. This distribution may had arisen from selective destruction of aerobic bacteria, thus leaving the resistant and adaptive anaerobic bacteria to proliferate in the polluted plots (Odu, 1981). The bacteria population was higher in control than organic fertilizer treated plots. Bacteria population decreased from $3.00 \mathrm{x}$ $10^{6} \mathrm{cfu} \mathrm{g}^{-1}$ as seen in Table 8 to $2.80 \times 10^{6} \mathrm{cfu} \mathrm{g}^{-1}$ and $2.85 \times 10^{6} \mathrm{cfu} \mathrm{g}^{-1}$ at control, 5 and 10 organic fertilizer treated plots respectively (Table 8 ). 
Reverse was the case for fungi population as spent engine oil pollution depressed it (Adedokun andAtaga, 2007). The highest fungi population was $0.75 \times 10^{6} \mathrm{cfu}$ $\mathrm{g}^{-1}$ obtained from control and least was obtained from $10 \%$ spent engine oil polluted soil. Organic fertilizer significantly influenced fungi population(Table 8). Plots that received organic fertilizer amendment showed significant increased in fungi population value than control.

From the Table 9, plots unpolluted and treated with $10 \mathrm{t} \mathrm{ha}^{-1}$ organic fertilizer had the highest fungi population $\left(7.70 \times 10^{5} \mathrm{cfu} \mathrm{g}^{-1}\right)$ which was at par with 5 $\mathrm{t}$ ha ${ }^{-1}$ organic fertilizer treated plots with spent engine pollution $\left(7.60 \times 10^{5} \mathrm{cfu} \mathrm{g}^{-1}\right)$.

Table 1: Physical and Chemical Properties of the Soil Prior to be Polluted with Spent Engine Oil and Variable Amended with Organic Fertilizer.

\begin{tabular}{ll} 
Variable & Value \\
\hline Sand $\left(\mathrm{g} \mathrm{kg}^{-1}\right)$ & 628 \\
Silt $\left(\mathrm{g} \mathrm{kg}^{-1}\right)$ & 164 \\
Clay $\left(\mathrm{g} \mathrm{kg}^{-1}\right)$ & 232 \\
Textural class & Sandy clay loam \\
$\mathrm{pH}\left(\mathrm{H}_{2} \mathrm{O}\right)$ & 5.00 \\
Organic C $(\%)$ & 2.00 \\
Total $\mathrm{N}(\%)$ & 0.08 \\
Available P $\left(\mathrm{mg} \mathrm{kg}^{-1}\right)$ & 5.70 \\
Exchangeable cations $(\mathrm{c} \mathrm{mol} \mathrm{kg}$ \\
$\mathrm{Ca}$ & \\
$\mathrm{K}$ & 0.70 \\
$\mathrm{Mg}$ & 0.16 \\
\hline
\end{tabular}

Table 2: Effects of Spent Engine Oil and Organic Fertilizer on Some Chemical Properties.

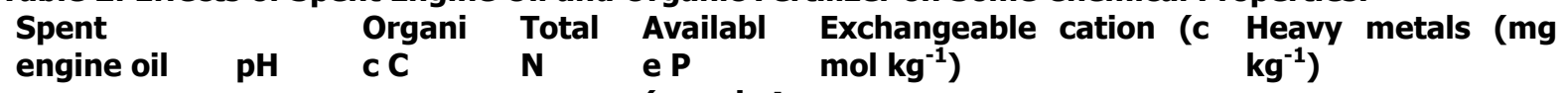

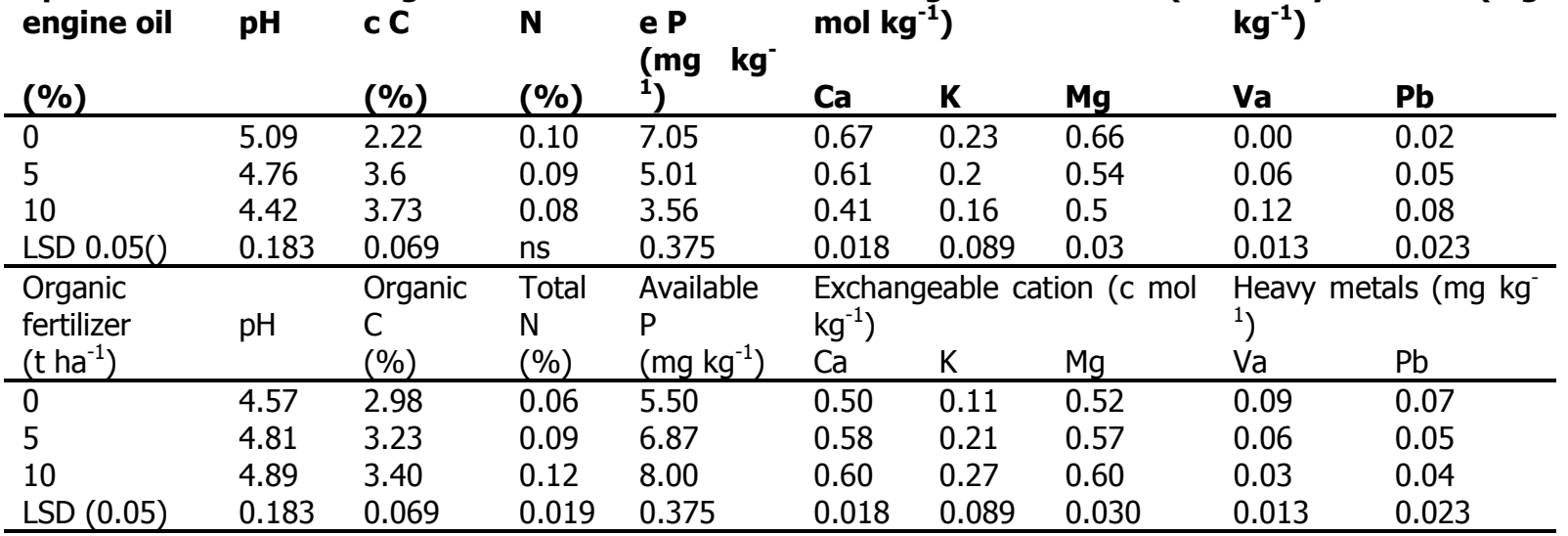

n.s - not significant at $5 \%$ level of probability

Table 3: Interactive Effects of Spent Engine Oil and Organic Fertilizer on Some Chemical Properties

\begin{tabular}{|c|c|c|c|c|c|c|}
\hline $\begin{array}{l}\text { Spent engine } \\
\text { oil } \\
(\%)\end{array}$ & 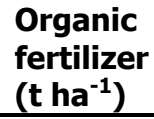 & $\begin{array}{l}\text { Organic } \\
\text { C } \\
(\%) \\
\end{array}$ & $\begin{array}{l}\text { Available } \\
\mathbf{P} \\
\left(\mathrm{mg} \mathrm{kg}^{-1}\right)\end{array}$ & $\begin{array}{l}\text { Exch } \\
\text { mol k } \\
\text { Ca }\end{array}$ & le ca & $\begin{array}{l}\text { Heavy metals } \\
\left(\mathrm{mg} \mathrm{kg}^{-1}\right) \\
\mathrm{Va}\end{array}$ \\
\hline 0 & 0 & 1.83 & 5.50 & 0.66 & 0.13 & 0.00 \\
\hline 0 & 5 & 2.27 & 6.87 & 0.67 & 0.24 & 0.00 \\
\hline 0 & 10 & 2.57 & 8.80 & 0.67 & 0.33 & 0.00 \\
\hline 5 & 0 & 3.50 & 3.80 & 0.54 & 0.11 & 0.09 \\
\hline 5 & 5 & 3.68 & 5.34 & 0.64 & 0.21 & 0.06 \\
\hline 5 & 10 & 3.80 & 5.88 & 0.64 & 0.27 & 0.04 \\
\hline 10 & 0 & 3.60 & 2.30 & 0.30 & 0.09 & 0.17 \\
\hline 10 & 5 & 3.74 & 3.92 & 0.44 & 0.19 & 0.13 \\
\hline 10 & 10 & 3.84 & 4.43 & 0.50 & 0.20 & 0.05 \\
\hline LSD (0.05) & & 0.119 & 0.650 & 0.032 & 0.033 & 0.022 \\
\hline
\end{tabular}


Table 4: Number of Leaves of $T$. occidentalis as Influenced by Spent Engine Oil Pollution and Organic Fertilizer Amendment

\begin{tabular}{llllll}
$\begin{array}{l}\text { Spent engine oil } \\
(\%)\end{array}$ & $\mathbf{2}$ & $\mathbf{4}$ & $\mathbf{6}$ & $\mathbf{8}$ & $\mathbf{1 0}$ \\
\hline 0 & 21.67 & 36.40 & 31.90 & 32.80 & 28.20 \\
5 & 15.44 & 25.70 & 26.00 & 29.30 & 28.10 \\
10 & 16.67 & 23.80 & 25.60 & 27.10 & 22.60 \\
LSD 0.05() & 4.959 & 6.290 & ns & ns & ns \\
\hline Organic fertilizer & \multicolumn{5}{c}{ Weeks After Transplanting } \\
$\left(\mathrm{t} \mathrm{ha}^{-1}\right)$ & 2 & 4 & 6 & 8 & 10 \\
\hline 0 & 10.00 & 17.80 & 21.70 & 18.10 & 19.60 \\
5 & 19.56 & 34.00 & 29.70 & 31.70 & 27.20 \\
10 & 24.22 & 34.10 & 32.10 & 39.00 & 32.60 \\
LSD $(0.05)$ & 4.959 & 6.290 & 8.460 & 7.480 & 8.660 \\
\hline
\end{tabular}

n.s - not significant at $5 \%$ level of probability

Table 5: Interactive Effects of Spent Engine Oil and Organic Fertilizer on Number of Leaves of T.occidentalis at two weeks after transplanting

\begin{tabular}{lll} 
Spent engine oil (\%) & Organic fertilizer $\left(\mathbf{t ~ h a}^{-\mathbf{1}}\right)$ & $\mathbf{N u m b e r}$ of leaves \\
0 & 0 & 14.33 \\
0 & 5 & 21.33 \\
0 & 10 & 29.33 \\
5 & 0 & 11.00 \\
5 & 5 & 19.67 \\
5 & 10 & 15.67 \\
10 & 0 & 4.67 \\
10 & 5 & 17.67 \\
10 & 10 & 27.77 \\
\hline LSD (0.05) & 8.589 \\
\hline WAT - Weeks after transplanting
\end{tabular}

Table 6: Effects of Spent Engine Oil and Organic Fertilizer on Growth and Herbage Yield of $\boldsymbol{T}$. occidentalis

\begin{tabular}{|c|c|c|c|c|c|c|c|}
\hline $\begin{array}{l}\text { Spent } \\
\text { engine oil } \\
(\%)\end{array}$ & $\begin{array}{l}\text { Tap root } \\
\text { length } \\
(\mathrm{cm})\end{array}$ & $\begin{array}{l}\text { Nos of } \\
\text { roots }\end{array}$ & $\begin{array}{l}\text { Vine } \\
\text { length } \\
(\mathrm{cm})\end{array}$ & $\begin{array}{l}\text { Dry vine } \\
\text { weight } \\
\text { (g) }\end{array}$ & $\begin{array}{l}\text { Dry root } \\
\text { weight } \\
\text { (g) }\end{array}$ & $\begin{array}{l}\text { Dry leaf } \\
\text { weight } \\
\text { (g) }\end{array}$ & $\begin{array}{l}\text { Herbage } \\
\text { yield } \\
\left(\mathrm{t} \mathrm{ha}^{-1}\right)\end{array}$ \\
\hline 0 & 8.54 & 13.56 & 58.70 & 3.20 & 10.73 & 11.62 & 7.49 \\
\hline 5 & 9.61 & 16.11 & 59.00 & 3.11 & 9.40 & 7.58 & 6.23 \\
\hline 10 & 10.29 & 12.28 & 56.00 & 2.40 & 7.76 & 9.8 & 6.19 \\
\hline LSD 0.05() & ns & ns & ns & 1.465 & ns & 2.621 & 1.263 \\
\hline $\begin{array}{l}\text { Organic } \\
\text { fertilizer (t ha- } \\
{ }^{1} \text { ) }\end{array}$ & $\begin{array}{l}\text { Tap root } \\
\text { length }(\mathrm{cm})\end{array}$ & $\begin{array}{l}\text { Nos of } \\
\text { roots }\end{array}$ & $\begin{array}{l}\text { Vine } \\
\text { length } \\
(\mathrm{cm})\end{array}$ & $\begin{array}{l}\text { Dry vine } \\
\text { weight }(\mathrm{g})\end{array}$ & $\begin{array}{l}\text { Dry root } \\
\text { weight }(\mathrm{g})\end{array}$ & $\begin{array}{l}\text { Dry leaf } \\
\text { weight }(\mathrm{g})\end{array}$ & $\begin{array}{l}\text { Herbage } \\
\text { yield }\left(\mathrm{t} \mathrm{ha}^{-1}\right)\end{array}$ \\
\hline 0 & 7.95 & 12.06 & 45.9 & 1.93 & 5.49 & 5.39 & 4.36 \\
\hline 5 & 10.37 & 14.56 & 59.40 & 2.64 & 9.93 & 8.66 & 7.05 \\
\hline 10 & 10.13 & 15.33 & 68.40 & 4.14 & 12.47 & 14.97 & 8.49 \\
\hline LSD (0.05) & ns & ns & 1.457 & 1.465 & 2.723 & 2.621 & 1.263 \\
\hline
\end{tabular}

ns - not significant at $5 \%$ level of probability

Table 7: Interactive Effects of Spent Engine Oil and Organic Fertilizer on Growth and Herbage Yield of $T$. occidentalis

\begin{tabular}{llll} 
Spent engine oil (\%) & Organic fertilizer $\left(\mathbf{t ~ h a}^{\mathbf{- 1}}\right)$ & Leaf dry weight $(\mathbf{g})$ & Herbage yield $\left(\mathbf{t ~ h a} \mathbf{~}^{\mathbf{- 1}}\right)$ \\
0 & 0 & 6.16 & 5.55 \\
0 & 5 & 8.42 & 7.68 \\
0 & 10 & 20.28 & 9.23 \\
5 & 0 & 5.68 & 4.37 \\
5 & 5 & 8.42 & 7.22 \\
5 & 10 & 8.64 & 7.10 \\
10 & 0 & 4.32 & 3.17 \\
10 & 5 & 9.14 & 6.25 \\
10 & 10 & 16.00 & 9.15 \\
\hline LSD $(0.05)$ & & 4.540 & 2.87 \\
\hline
\end{tabular}




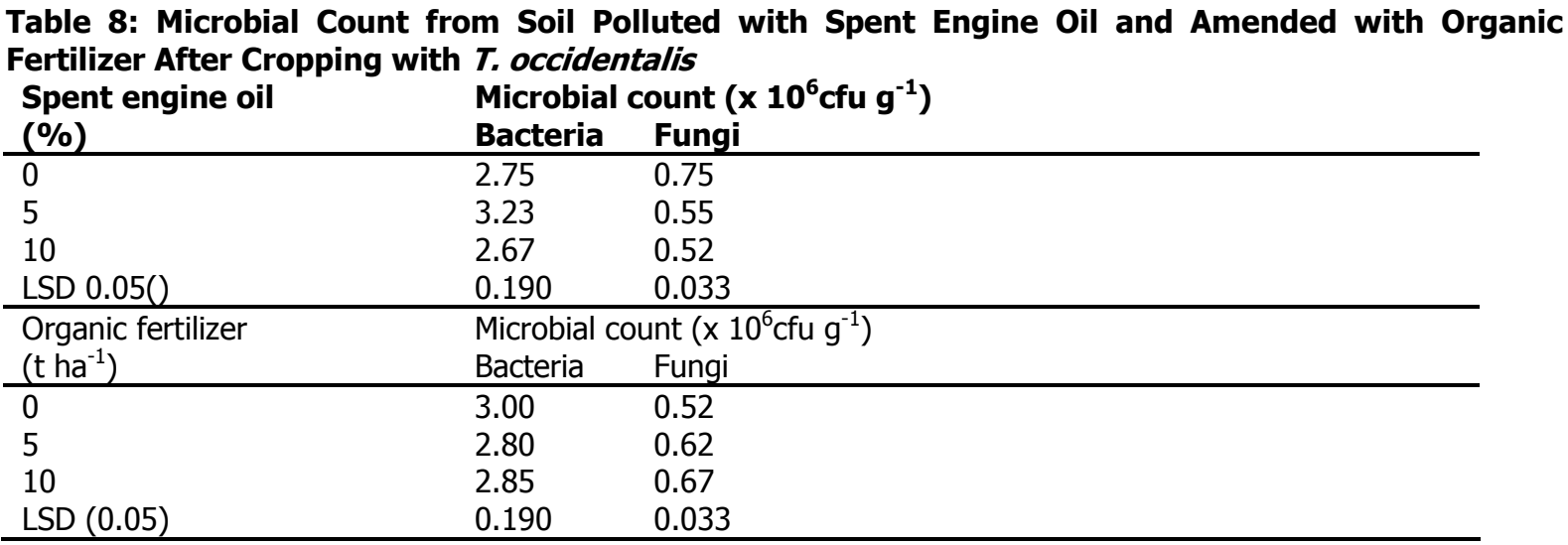

\begin{tabular}{|c|c|c|}
\hline $\begin{array}{l}\text { Spent engine oil } \\
(\%)\end{array}$ & $\begin{array}{l}\text { Organic fertilizer } \\
(\mathrm{t} \mathrm{ha})\end{array}$ & $\begin{array}{l}\text { Microbial count }\left(\times 10^{6} \mathrm{cfu} \mathrm{g}^{-1}\right) \\
\text { Fungi }\end{array}$ \\
\hline 0 & 0 & 0.70 \\
\hline 0 & 5 & 0.76 \\
\hline 0 & 10 & 0.77 \\
\hline 5 & 0 & 0.47 \\
\hline 5 & 5 & 0.57 \\
\hline 5 & 10 & 0.62 \\
\hline 10 & 0 & 0.40 \\
\hline 10 & 5 & 0.54 \\
\hline 10 & 10 & 0.61 \\
\hline LSD (0.05) & & 0.057 \\
\hline
\end{tabular}

\section{CONCLUSION AND RECOMMENDATION}

Organic fertilizer effectively remediated the spent engine oil polluted soil through improvement of soil chemical properties and microflora. In addition, it enhanced growth and herbage yield of fluted

\section{REFERENCES}

Adedokun, O. M. andAtaga, A. E. 2007. Effects of amendments andbioaugumentation of soil polluted with crude oil, automotive gasoline oil,and spent engine oil on the growth of cowpea (Vignaunguiculata L.Walp). Scientific Research and Essay, 2(5):197-149.

Amadi, A., Samuel, D. A. and Anthony, M. (1994). The effect of crude oilspillage on the soil microbial properties of a tropical rainforest.Journal of Water, Air and Soil Pollution 67 (1-3): 28-30.

Anoliefo, G. O., Vwioko, D. E. (1995). Effects spent lubricating oil on the growth of Capsicum annum L. and Lycopersiconesculentum Miller. Environmental Pollution, 88: 361-364.

ATSDR (Agency for Toxic Substances and Disease Registry) (1997).Toxicology. Profile for used mineral base crankcase oil. Department of Health and Human Services, Public Health Service Press, Atlanta, GA, USA.

Atuanya, E. I. (1987). Effects of waste engine oil pollution on physical and chemical properties of soil: A case study of waste oil contaminated Delta soil in Bendel State, Nigerian Journal of Applied Science, 5: 155-175.

Baek, K., Kim, H., Oh, H., Yoon, B., Kim, J., and Lee, I. (2004). Part A-Toxic/Hazardous Substances pumpkin. Amendment of spent engine oil polluted soil with organic fertilizer is being recommended to boost crop production putting spent engine contaminated site into productive use.

and Environmental Engineering Journal of Environmental Science and Health, 39: 24652472.

Collins C. H, Lyne, P. M (1976). Microbial Methods. Butterworth and Company Ltd. Great Britain pp. 159-427.

De Jong, E. (1980). The effect of crude oil spill on cereals. Environmental Pollution, 22:172-187

Fagbemi, T.N.F., Eleyinmi, A.F. Atum, H.N. and Akpanbang,O.(2005). Nutritional composition of fermented pumpkin seed for production of ogiriugu. Proceedings off the IFT annual meeting. P54B2, session 54B, fermented food and beverages: General

Fawole M. O. andOso, B. A (1988).Laboratory Manual of Microbiology. Spectrum Book Ltd., Ibadan p. 127.

GENSTAT (2005).Gentstat Release 8.1. Statistical Software.VSN International Ltd, Rothamsted, UK.

Jones, T. G, and Edington, M. A. (2005). An ecological survey of hydrocarbon oxidizing microorganisms. Journal of General. Microbiology, 52: 389-393

Marchner, H (1995). Mineral Nutrition of Higher Plants (2nd ed.). New York, Academic Press, $889 \mathrm{pp}$. 
Merkl, N, Schutze-Kraft, R. and Arias, M. (2005). Influence of fertilizer level on phytoremediation of crude oilcontaminated soils with the tropical grass Brachiaria brizantha (Hochst. ex A. Rich.) Stapf. In: Phytoremediation of petroleum- contaminated soil. Merkl, N. (Ed), Margraf Publisher, Weikershim, 2005; pp 71-83

Muanya, C. (2012). How fluted pumpkin diet prevent sperm damage, diabetes, cancer. http://www.ngrguardiannews.com/index.php.

Mylavarapus, R. S and Kennelley, D. E. (2002). Extension soil testing laboratory (ESTL): Analytical procedures and training manual. Institute of Food and Agricultural Science, University of Florida, Gainsville, USA.

Odu, C. T. I. (1981). Degradation and weathering of crude oil under tropical condition. In: Proceeding of an International Seminar on the Petroleum Industry and the Nigerian Environment. November 1981, Petroleum Training Institute, Warri, Nigeria.

Ogboghodo, I. A.,Azenabor, U. F. andOsemwota, I. O. (2005). Amelioration of crude oil polluted soil with poultry manure and the effecton growth of maize and some soil properties. Journal of Plant Nutrition28(1): 21-32

Oguntola, S. (2011). Fluted pumpkin for prostate problem, diabetes. http://tribune.com.ng/index.php/naturalhealth.

Ojeniyi S.O (2000). Effect of goat manure on soil nutrients and okra yield in a rain forest area of Nigeria. Applied Trop. Agric. 5: 2023.

Okon, I. E. andUdofot, E. E.(2012). Response of Telfairia occidentalis (Hook) to Arbuscular mycorrhizal fungi and Gliricidia sepium leaves manure in spent engine oil contaminated soil. World Journal of Agricultural Sciences 8 (1): $20-25$

Udo E.J. and Fayemi A.A.A. (1975).The effect of oil pollution on soil germination, growth and nutrient uptake of corn.Journal of Environmental Quality4: 537- 540.

Udom, B. E., Mbagwu, J. S. C. and Willie, E. S. (2008). Physical properties and maize production in a spent oil-contaminated soil bioremediated with legumes organic nutrients. Agro-Science Journal of Tropical Agriculture, Food, Environment and Extension 7 (1): 33-40. 